\title{
AİLE, ÇALIŞMA VE SOSYAL HIZZMETLER BAKANLIĞINA BAĞLI KURULUŞLARDA GÖREV YAPAN MESLEK ELEMANLARININ YAŞLILARA YÖNELİK TUTUMLARININ BELIRLENMESİ: ANKARA ÖRNEĞİ
}

Nur Eda KOÇ${ }^{1}$, Veli DUYAN ${ }^{2}$

\section{$\ddot{O} z$}

Yaşlı nüfusun hızla arttığı toplumlarda yaşlı bakım hizmetleri önem kazanmıştır. Bu alanda çalışan meslek elemanlarının yaşlılara karşı tutumlarının bakım hizmetlerinin kalitesini doğrudan etkilediği bilinmektedir. Meslek elemanları eğitim almalarına rağmen içinde bulundukları toplumun sosyo-kültürel özelliklerinden etkilenerek kalıp yargılar ve tutumlar geliştirmektedirler. Bu nedenle yaşlılara yönelik tutumlarının belirlenmesi önem arz etmektedir. Bu çalışmanın amacı Aile, Çalışma ve Sosyal Hizmetler Bakanlığına bağlı kuruluşlarda görev yapan meslek elemanlarının yaşlılara yönelik tutumlarını belirlemektir.

Veriler 268 katılımcı ile yüz yüze görüşülerek anket yoluyla toplanmıştır. Verilerin toplanmasında Demografik Bilgi Formu ve Kogan’ın geliştirmiş olduğu Yaşlılara Yönelik Tutum Ölçeği'nin Türkçe sürümü uygulanmıştır. Çalışma betimleyici ve kesitsel nitelik taşımaktadır. Sonuçlar SPSS 16 istatistik programı ile değerlendirilmiștir. Değișkenler arasındaki ilișki ve anlamlı bir farklılık olup olmadığının belirlenmesi için t-testi ve Varyans Analizi (Anova) kullanılmıştır.

Meslek elemanlarının yaşlılara yönelik tutumlarında gönüllü olarak yaşlılara hizmet veren bir kuruluşta çalışmış olma veya gelecekte böyle bir kuruluşta çalışma isteği, yaşlılık alanında kendini başarılı hissetme ve eğitim durumu değişkenlerinin olumlu yönde etkili olduğu belirlenmiștir. Mesleklere göre yaşlılara yönelik tutumun pozitiften negatife doğru sıralamanın psikolog, sosyal hizmet uzmanı, öğretmen, çocuk gelişimci ve diğer personel şeklinde olduğu tespit edilmiștir.

\section{Anahtar Kelimeler: Yaşlılar, Tutum, Meslek Elemanları, Yaşlılık}

${ }^{1}$ B.U. Nur Eda Koç, Ankara Aile, Çalışma ve Sosyal Hizmetler İl Müdürlüğü, e-posta kocnureda@yahoo. com; Orcid No: 0000-0002-7628-1000

${ }^{2}$ Prof. Dr. Veli Duyan, Ankara Üniversitesi, Sağlık Bilimleri Fakültesi, Sosyal Hizmet Bölümü, e-posta vduyan@health.ankara.edu.tr:, Orcid No: 0000-0003-4316-5756 


\section{DETERMINATION OF THE ATTITUDES OF THE PROFESSIONALS TOWARDS THE ELDERLY WHO ARE EMPLOYED BY INSTITUTIONS OF THE MINISTRY OF FAMILY, LABOR AND SOCIAL SERVICES: ANKARA SAMPLE}

\section{Abstract}

It has been known that the attitudes towards the elderly of the professionals working in this field and their geriatric competencies directly affect the quality of the elderly care services. Although the professionals are educated, they are influenced by the socio-cultural features of their society; thus developing stereotyped judgments and attitudes. Therefore, the identification of their attitudes towards the bears importance. The purpose of this study is to identify the attitudes towards the elderly of the professionals within the Ministry of Family Labor and Social Services.

The data were collected through questionnaires during face to face interviews with 268 participants. Demographic Information Form and Turkish version of Kogan's Attitudes towards the Elderly Scale were applied for data collection. The study has descriptive and crosssectional qualifications. The results were evaluated via the statistics program SPSS 16.

It has been found that volunteering and will to work in an institution serving the elderly, affect positively the attitudes toward elderly. According to the professions, the attitude towards the elderly has been determined to be in the order of positive to negative, psychologist, social worker, teacher, child development and the other service workers.

Key Words: Older people, Attitudes, Proffesionals, Ageing 


\section{Girisis}

Yaşlanma bütün canlıların maruz kaldığg yaşamın doğal bir evresidir. İnsan da doğası gereği bu süreci yaşamakta ve değişikliklere uyum sağlamaya çabalayarak yaşamını sürdürme gayreti içerisine girmektedir. Fizyolojik, psikolojik, sosyal ve ekonomik değişiklikler ve gerilemeler bu dönemde hızla yaşanmaktadır (Tufan, 2006). İnsan bu değişimleri edindiği birikim, sahip olduğu kişilik yapısı, kültürel altyapı ve imkanlar ölçüsünde tolere ederek kaliteli bir hayat sürdürmektedir. Bu imkanlar sübjektif ve objektif refah göstergeleri olarak ayrılmakta ve yaşlılıkta alınan hizmetler de bu refah göstergelerinin bir parçası haline gelmektedir (Özmete, 2008).

Farklı disiplinlerden gelen yaşlılık alanında çalışan meslek elemanlarının yaşlılara karşı tutumları, yaşlılıkla gelen fiziksel kayıpların, fizyolojik değişimlerin, sosyal ve psikolojik sorunların doğru müdahale ve yaklaşımlarla çözümünde etkili bir faktördür. Meslek elemanlarının yaşlılara karşı geliştirdikleri olumlu tutumlar profesyonel hayatlarında etkili çözümlerin zeminini oluşturmaktadır. Sosyal hizmet başta olmak üzere birçok disiplin yaşlılık alanında profesyonel müdahalenin bir parçasıdır. Dolayısıyla ortaya çıkan hizmet, yaşlılık alanına temas eden bütün meslek gruplarının oluşturduğu ortak bir kalite standardını oluşturmaktadır.

$\mathrm{Bu}$ çalışma Aile, Çalışma ve Sosyal Hizmetler Bakanlığına bağlı kuruluşlarda çalışan meslek elemanlarının yaşlılara yönelik tutumlarının belirlenmesi amacıyla yapılmış öncü çalışmalardan biri olması bakımından önem taşımaktadır.

Ülkemizde sosyal hizmet alanında bakım elemanı olarak çalışanlarla ilgili tutum ölçeği uygulaması yapılmış olmakla birlikte, sosyal hizmet çalışanları ile bu tür bir çalışma henüz gerçekleştirilmemiştir. Literatürde öğrencilerle yapılmış birçok tutum belirleme araştırması mevcuttur. Aile, Çalışma ve Sosyal Hizmetler Bakanlığı bünyesinde görev yapan bütün meslek gruplarının yaşlılara yönelik tutumlarının belirlenmesi, bakımından da önem taşımaktadır. Yurt dışında yapılan çalışmaların sosyal, kültürel ve ekonomik farklılıklar nedeniyle ülkemizdeki bu alana ışık tutma imkânı bulunmamaktadır. Yapılacak olan bu çalışmayla bu alandaki eksikliğin giderilmesi amaçlanmaktadır. 
Ayrıca sosyal hizmetin önemli bir alanı olan yaşlı hizmetlerinde görev yapan personelin mevcut hizmet standartlarının belirlenmesi ve geliştirilmesinde önemli bir katkı sağlayacağı düşünülmektedir.

Bakanlık bünyesinde hizmet verilen engelli, yaşlı, çocuk ve kadın hizmetleri gibi ana alanlar arasında personel geçişi sıkça yapılmaktadır. Geçiş yapılırken yaşlılık alanında görevlendirilecek personelde bulunması gereken niteliklerin tespit edilmesinde kriter belirlemede ve alana uyum sağlayacak personelin seçiminde rol oynayacaktır.

Yaşlı hizmetlerinde görev almaktayken personelin birtakım eksiklerinin tespit edilmesi, hizmet içi eğitimler ve projeler yoluyla yetkinlik seviyelerinin yükseltilmesinin sağlanmasında önem arz etmektedir. Bu amaçla geliştirilecek bütün müdahale araçlarına teorik bir kaynak olarak yol göstermesi açısından önem taşımaktadır.

\section{Yașlilara Yỏnelik Tutum}

Toplumların sosyokültürel yapıları ve gelenekleri, değiş̧ik alanlardaki tutum ve davranışlarını büyük ölçüde belirlemektedir. Diğer birçok alanda olduğu gibi yaşlıya karşı tutum ve davranışların oluşumu da bu geleneksel ve sosyo-kültürel özelliklerden etkilenmektedir (Akdemir vd., 2007). Tutumların gelişiminde tutum geliştiren bireyin geçmiş yaşantısı, deneyimleri, eğitim durumu ve sahip olduğu kültürde yaşlılara ve yaşlıya geliştirilen tutum rol oynamaktadır (Öz, 2002,ss. 17).

Yaşlı bireylerin yaşlılığa yönelik tutumlarını inceleyen çalışmalarda günlük yaşam aktivitelerini yerine getirme konusunda yetersiz olan, sosyoekonomik düzeyi düşük olan ve sağlık durumu iyi olmayan yaşlı bireylerin yaşlılıkla ilgili tutumları olumsuz olarak; $60-74$ yaş grubundakiler 75 ve üzeri yaş grubundakilerden daha pozitif, evli olanların evli olmayanlardan daha pozitif, düzenli geliri olanların olmayanlardan, kronik hastalığı olmayanların olanlardan daha pozitif bir tutuma sahip olduğu tespit edilmiştir (Özpınar ve Korkmaz, 2017;Özyurt vd., 2013,ss.29).

Literatürde tecrübe, yaş ve cinsiyetin yaşlllığa yönelik tutumlar konusunda etkili faktörler olduğu söylenmiştir (Söderhamn vd, 2001. ss.225; Slevin 
1991,ss. 1197). Kız öğrencilerin erkek öğrencilerden daha olumlu tutuma sahip olduğu görülmüştür (Elbi vd., 2015). Genel olarak erkek katılımcıların kadın katılımcılara göre yaşliya yönelik tutumlarda daha negatif olduğu görülmüştür (Hawkins, 1996,ss.271). Ayrıca tutumun yöneldiği yaşlı bireylerin yaşı ve cinsiyetinin de tutum geliştirenler üzerinde etkili olduğu belirtilmiştir.

Eğitim tutumlar üzerinde etkili faktörlerden biridir. Geriatrik eğitimin tıp öğrencilerinin yaşlılara yönelik tutumlarını olumlu yönde geliştirdiği Warren (1983) tarafından bildirilmiştir (ss.435). Bir diğer çalışmada profesyonel eğitimi yüksek seviye olan hemşirelerin yaşlılara karşı tutumlarının daha olumlu olduğu belirtilmektedir (Armstrong-Esther vd., 1989,ss.34). Söderhamn’n (2001) yaptığ1 çalışmada da hemşirelerin hemşirelik öğrencilerinden daha olumlu tutuma sahip oldukları vurgulanmıştır (ss.225). Bir diğer çalışmada duyarlılık eğitimine ve yaşlanmayla ilgili bilgilere odaklanan altı haftalık bir eğitim programından önce ve sonra tıp öğrencilerinin tutumları ölçülmüştür. Sonuçlar öğrencilerde yaşlı hastalarla çalışmak için gereken tutum ve becerilerin geliştiğini göstermiştir (Intrieri vd.\& Castilla, 1993 ss.373).

Kültürel özelliklerin tutum üzerinde etkili olduğunu gösteren çalışmalarda katılımcıların geleneksel bakış açısından, toplumlarında yaşlı bireye yönelik tutumdan etkilendikleri belirtilmiştir. (Seng Kwing Cheong vd., 2009 s.850; Ceylan vd., 2015 ss.459).

Depaola ve arkadaşları (1994) bakım evi personeli göz önüne alınarak ölüm kaygısı ve yaşlılara karşı tutum arasındaki ilişkiye değinen bir çalışma yayınlamıştır(ss.231). Yaş ayrımcılığına ilişkin inançlar ve kalıp yargıların sosyal hizmet uzmanlarının inançlarını, tutumlarını ve yaşlılarla olan etkileşimlerini etkilediği yaygın olarak görülmektedir (Dalley, 1996,ss.515; Peace vd., 1996,ss36). Quinn (1999;ss.171) öğrencilerle yaptığ 1 çalışmada tutumların duygusal bileşenlerinin gözden kaçırıldığını söylemektedir. Duygusal ilişkiler öğrencilerin yaşlılara ve yaşlılarla sosyal hizmete karşı tutumunu etkilemektedir. Yaşlılarla temas halinde eğitime devam eden öğrencilerin kendilik farkındalığında artış ve ölen veya yakınlarını kaybeden kişilere müdahalede de gelişme sağladıklarını bildirmiştir. İsveç’te Fagerberg ve Erkman'ın (1997;ss.177) çalışmasında hemşirelik öğrencilerinin yaşlı hastalarının hastalıklarından, yardımsızlıklarından, bağımsızlıkları için 
mücadelelerinden ve kimliklerinden duygusal olarak etkilendikleri tespit edilmiştir. Ayrıca yapılan bir çalışmada aile içinde yaşlı bireyle birlikte yaşayanların yaşamayanlara göre yaşlıya yönelik olumlu ayrımcılık puan ortalamalarının anlamlı düzeyde yüksek olduğu saptanmıştır (Ünalan vd., 2012,ss.115). Üniversite öğrencileriyle yapılan bir çalışmada da yaşlı bakımında gönüllü yer almanın gençlerin kendi bireysel gelişimlerine meslek hayatlarına ve profesyonelliklerine olumlu yönde katkıda bulunacağına ilişkin inanç taşıdıkları ortaya konmaktadır ( Hablemitoğlu, Özmete,2011). Gallagher (2006;ss.273) yardımcı personel ile hemşireler arasında olumsuz tutumlarda kayda değer fark bulmuştur.

Yaşlılıkla ilgili tutumların çalışma alanı tercihini etkilediğini gösteren birtakım bulgular elde edilmiştir. Yun-e Liu ve arkadaşlarının (2012;ss.397) sistematik gözden geçirmesinde İngilizce ve Çince kaynakları tarayarak 25 makale tespit edilmiş ve 2000 yılından itibaren hemşirelerin ve hemşirelik öğrencilerinin tutumlarının daha az olumlu olduğu belirlenmiştir. Yaşlı insanlarla çalışmaya yönelik tercih ve yaşlılık bilgisinin yaşlı insanlara yönelik olumlu tutumlarla ilişkili olması çalışmalar arasında en tutarlı sonuç görülmüştür. Mckinlay ve Cowan (2003;ss.298) tarafından yapılan bir çalışmada İngiltere'de yaşlı nüfusun artışının geriatrik hemşirelik alanının önem kazanmasını sağlamasına rağmen istihdam istatistiklerinde bu alanın popüler olmadığı görülmüş ve bunun hemşirelik öğrencilerinin yaşl1lığa yönelik olumsuz tutumlarından kaynaklanabileceğini ileri sürülmüştür. Artan geriatrik sosyal hizmet uzmanı ihtiyacına karşın sosyal hizmet bölümü öğrencilerinin yaşlı müracaatçılarla çalışma konusundaki kararsızlık düzeylerinin de arttığı bildirilmiştir (Scharlach vd., 2000,ss. 521). Gorelik, Damron ve arkadaşları (2000,ss.623) tarafından gerontoloji alanında eğitim alan öğrencilerle ilgili olarak iki engel bulunduğu belirtilmiş ve bunlar 1) öğrenci direnci 2) yaşlı bireyleri düşük öncelikli müracaatçılar olarak görme şeklinde tanımlanmıştır. İngiltere'de mezun olan sosyal hizmet öğrencileriyle yapılan bir çalışma yaşlı müracaatçılarla çalışmanın en az popüler seçenek olduğunu ve bu alandaki seçimin okula başlama ve mezuniyet arasındaki farkın çok az olduğunu göstermiştir (Jack ve Mosely, 1997,ss. 893-911).

Yaşlilara yönelik olumsuz tutumlar yalnızca sosyal hizmet öğrencilerine has bir durum değildir. Amerika’da 299 beslenme diyetetik öğrencisiyle 
yapılan çalışmada öğrencilerin hangi yaş grubuyla çalışmak istedikleri sorusuna verdikleri cevaplara bakıldığında, yaşlı grupları en düşük sırada tercih ettikleri görülmüştür. Ayrıca öğrencilerin yaşlılıkla ilgili bilgi sahibi olmadıkları, yaşlılara karşı tarafsız bir tutuma sahip oldukları ortaya çıkmıştır (Kaempfer vd., 2002,ss. 197). Sağlık personelinin yaşlıların kronik sorunlarıyla uğraşmaktansa genç hastaların hızlı iyileşme potansiyeli olan akut rahatsızlıkları konusunda çalışmayı tercih ettikleri belirtilmiştir (Öz, 2002,ss. 17).

Yaşlanan nüfusun ihtiyacını karşılamak açısından gelecekte yaşlılık alanında çalışmak isteyen sosyal hizmet uzmanlarının sayısı önem arz etmektedir. Mason ve Sanders (2004) tarafından yapılan çalışmada 22 sosyal hizmet yüksek lisans öğrencisiyle, öğrencilerin yaşlı müracaatçılarla çalışmak konusundaki tutumlarını belirlemek için yüz yüze görüşme yapılmıştır (ss.61). Araştırmada yaşlı bireylerle çalışan öğrenciler tercih edilmiştir. Yarıya yakını yaşlılık alanını isteyerek seçmediğini ifade etmiştir. Gerontoloji alanında çalışma konusunda öğrencilerin motivasyonu, öğrenim firsatları ve öğrencilerin yaşlılık alanında çalışmaya hazırlanmasına ilişkin hususlar öne çıkmıştır. Motivasyon kaynağına verilen cevaplarda öğrencinin kendi ilgi alanı olması gerektiği vurgulanmış, gerontoloji ile ilgili derslerin, oryantasyon programlarının, edebiyat paketlerinin ve gezilerin de motivasyon aracı olabileceği belirtilmiştir. Öğrenme fırsatları konusunda ise eğitim içerisinde yaşlı kişilerin hikayelerine yer verilmesinin yaşlıların insan olduklarının fark edilmesini sağlayacağı belirtilmiş, öğrencilerin yaşlılık alanında çalışmaya hazırlanması ile ilgili olarak da alanda vakalara ve olaylara maruz bırakılma yoluyla öğrencilerin hazırlanabileceği söylenmiştir. Ayrıca öğrencilerin kariyer yapma konusundaki çalışmalarının desteklenmesi gerektiği de katılımcılar tarafından bildirilmiştir.

Tutum üzerinde çalışma süresinin etkili olduğunu gösteren bir çalışma da Hellzen ve arkadaşları (2003;ss616) tarafından yapılmıştır. Bu çalışmada uzun süre şizofreni hastası olan yaşlılarla çalışan hemşirelerin duyarlılıklarının azaldığı, daha kısa süre çalışmış olan hemşirelerin ise daha duyarlı davrandıkları tespit edilmiştir. Bu sonuç yaşlılar ile çalışma süresinin de tutumlar üzerinde etkili olduğuna ilişkin örnek teşkil eden bir çalışma olmuştur. 
İletişimin tutumla ilgili temel bir kavram olduğunu göstermesi bakımından Schwartz (2001;ss127) Allport’un (1954) geliştirmiş olduğu “temas hipotezi" ile yaşlı bireylere yönelik tutumun ilişkisini gösteren bir çalışma gerçekleştirmiştir. Allport dış-grup üyeleriyle olumlu kurulan temasın tüm dış-grup üyelerine genelleneceğini, dış-gruba yönelik önyargının azalacağını ve kalıp yargıların değişeceğini düşünmüştür. 62 öğrenciye yaşlı bireylerle olan temas sıklığı ve kalitesi ile yaşlılara yönelik örtülü tavırları değerlendiren tek bir anket verilmiştir. Sonuçlar olumlu iletişim kalitesinin, temas sıklığıyla değil, yaşlılara karşı daha olumlu tutumlarla ilişkili olduğunu göstermiştir.

Bir araştırma da kuşaklar arası pozitif temasın genç insanların yaşlı yetişkinlere yönelik tutumlarını geliştirebileceğini göstermektedir. Düzenli olarak iş yerinde yaşlılarla etkileşime giren gençlerin yaşlı insanlara karşı daha olumlu tutum sergiledikleri, daha yaşlı akrabalarıyla yaşayanların ise daha yaş ayrımcı tutumlara sahip oldukları belirlenmiştir (Allan ve Johnson, 2009,ss.1).

Tutum ve iletişim bağlantısını konu alan bir araştırma kapsamında yapılan bir dizi çalışmada elde edilen sonuçlar, yaşlı erişkinlerle sık temasın yaş ayrımcılığını azaltmak için yeterli olmayabileceğini, bunun yerine, ayrımcılığı azaltma potansiyeline kuşaklararası temasın algılanan kalitesinin sahip olduğu ortaya konmuştur. Bu sonuçların sağlamlığını test etmek ve ayrıca doğrudan nesillerarası temas ile gençlerin yaşlı erişkinlere yönelik tutumları arasındaki pozitif ilişkilerin potansiyel ara bulucuları olarak gruplararası kaygı ile yaşlanma kaygısını incelemek amacıyla ikinci bir araştırma yapılmıştır. Bu araştırma 110 psikoloji bölümü öğrencisi üzerinde gerçekleştirilmiştir. Katılımcılar puanlama yapmış ve yüksek skorlar yaşlanma anksiyetesini göstermiştir. Araştırmaların sonuncusunda yaşları 18 ile 30 arasında değişen 95 genç ile internet aracılı̆̆ı ile ankete katılmıştır. Bu çalışmaların sonuçları, yaşlılarla iyi kalitede doğrudan temas kurmanın birçok genç insan için kuşaklararası buluşma endişelerini azalttığını ve bunun da kuşkusuz yaşlı yetişkinlere yönelik tutumlarını bir bütün olarak geliştirdiğini ortaya koymaktadır. Ayrıca yaş ayrımcılı̆̆ının azalması için gençlerin doğrudan yaşlıyla iletişime geçmesinin çok gerekli olmayabileceği, bunun yerine diğer gençlerin yaşlı bireylerle ilişkilerinin iyi olduğunu bilmenin bu etkiyi yapacağı öngörülmektedir. Mevcut sosyal iklimde özellikle gençler ve yaşlı yetişkinler arasındaki uçurumun genişlediği ve 
kuşaklar arası doğrudan temas firsatlarının gittikçe sınırlı hale geldiği de görülmektedir (Drury vd., 2016,ss.522).

Sonuç olarak yaşlılık sosyal hizmetin ana alanlarından biri olmakla birlikte spesifik bir konudur. Çalışmanın temel stratejisi meslek elemanlarının yaşlılıkla ilgili zayıf ve güçlü yönlerinin ortaya konularak hizmet kalitesinin geliştirilmesidir.

\section{Araştırmanın Amacı}

Bu çalışmada Aile, Çalışma ve Sosyal Hizmetler Bakanlığı’nda çalışan meslek elemanlarının yaşlılara karşı tutumlarının belirlenmesi amaçlamıştır. Araştırma yaşlılara yönelik tutumu etkileyen faktörleri incelemek ve aralarındaki ilişkiyi değerlendirmek amacıyla yapılmıştır.

Araştırmanın amacına bağlı olarak aşağıdaki sorulara yanıt aranmıştır:

- Meslek elemanlarının sosyo-demografik özelliklerine göre yaşlılara yönelik tutumları farklılaşmakta mıdır?

- Meslek elemanlarının ailesinde yaşlı birey olması durumuna göre yaşlılara yönelik tutumları farklılaşmakta mıdır?

- Meslek elemanlarının ilgisi yaşlılık alanına göre yaşlılara yönelik tutumları farklılaşmakta mıdır?

- Meslek elemanlarının çalışma yaşamına ilişkin özelliklerine göre yaşlılara yönelik tutumları farklılaşmakta mıdır?

\section{Yöntem}

\section{Araștırmanın Șekli}

$\mathrm{Bu}$ araştırma; Aile, Çalışma ve Sosyal Hizmetler Bakanlığına bağlı kuruluşlarda görev yapan meslek elemanlarının yaşlılara yönelik tutumlarını belirlemeye, buna etki eden sosyo-demografik özellikler, meslek elemanlarının ailelerinde yaşlı birey olması durumu, çalışma yaşamı ve meslek elemanlarının yaşlılık alanına ilgisi gibi faktörlerin etkisini saptamaya yönelik tanımlayıcı, kesitsel, nicel bir araştırmadır. 


\section{Araștırmanın Evreni}

Araştırmanın çalışma evrenini, Aile, Çalışma ve Sosyal Hizmetler Bakanlığına bağlı Ankara ili içerisinde bulunan bütün kuruluşlarda görev yapan bütün meslek elemanları oluşturmaktadır. Sosyal hizmet kuruluşlarında görev yapan sağlık servislerinde görevli hekim, fizyoterapist, diyetisyen, hemşire, sosyal serviste görev yapan sosyal hizmet uzmanı, psikolog, çocuk alanında hizmet veren kuruluşlarda görevli çocuk gelişimci ve öğretmenler ile il müdürlügünde görev yapan bütün anılan meslek gruplarıla birlikte sosyologlar da araştırmaya dahil edilmiştir. Araştırmanın veri toplama sürecinde 552'si yatılı hizmet veren 19 kuruluşta ve İl müdürlüğünde, 100'ü sosyal hizmet merkezlerinde olmak üzere 652 meslek elemanı bulunmaktadır. Sosyal hizmet merkezleri dışında diğer kuruluşlarda ve il müdürlüğünde çalışan 552 meslek elemanından farklı nedenlerle 268 personele ulaşılabilmiştir.

\section{Araştırmanın Örneklemi}

Örneklemde yer alan bağlı kuruluşlar ve İl Müdürlüğünde yer alan şubeler; Elmadağ Huzurevi Yaşlı Bakım ve Rehabilitasyon Merkezi Müdürlügü (HYBRM), Gicik HYBRM, 75.Yll HYBRM, Çubuk Abidin Yllmaz HYBRM, Kızılcahamam HYBRM, Seyranbağları HYBRM, Ümitköy HYBRM ve Yaşlı Hizmetleri Şube Müdürlüğü, Saray Sevgi Evleri Kız Yurdu Müdürlüğü, Saray Çocuk Evleri Sitesi Müdürlügü, Atatürk Çocuk Yuvası Müdürlüğü, Atatürk Çocuk Destek Merkezi Müdürlüğü, Ayaş Çocuk Destek Merkezi Müdürlüğü, Çocuk Hizmetleri Şube Müdürlüğü, Saray Engelsiz Yaşam Bakım ve Rehabilitasyon Merkezi, Şereflikoçhisar Bakım ve Rehabilitasyon Merkezi, Yenimahalle Görme Engelliler Rehabilitasyon Merkezi ve Engelli Hizmetleri Şube Müdürlüğü, 1.,2.,3. Kadın Konukevi Müdürlükleri, Koza Şiddeti Önleme İzleme Merkezi Müdürlüğü, Kadın Hizmetleri Şube Müdürlüğü’dür.

\section{Veri Toplama Araçları}

Araştırmada sosyo-demografik özellikler, eğitim durumu ve çalışma durumu başlıkları altında toplanan 18 soruluk Demografik Bilgi Formu oluşturularak kullanılmıştır. 
Yaşlılara yönelik tutumu belirlemek amacı ile de Duyan ve Gelbal tarafından 2013 yılında Türkçeye uyarlama çalışması yapılan Yaşlılara Yönelik Tutum Ölçeği (Kogan, 1961) kullanılmıştır.

Yaşlılara Yönelik Tutum Ölçeği Kogan tarafından 1961 yılında insanların yaşlılara yönelik tutumlarını ölçme amacıyla geliştirilmiştir. Ancak Türkiye’de yaşlılığa karşı tutumu ölçecek herhangi bir ölçme aracı bulunmaması nedeniyle Duyan ve Gelbal tarafından 2013 yılında Türkçeye uyarlama çalışması yapılmış ve yüksek güvenirlik ve geçerlilik sağlamıştır. Yaşlılara Yönelik Tutum Ölçeği kendi kendini bildirim tarzında bir değerlendirme aracıdır. 34 maddeden oluşan yaşlılara yönelik olumlu ve olumsuz tutumları yansıtan bu ölçek iki boyutlu bir ölçme aracıdır. Ölçekte yer alan ilk 17 madde olumsuz tutum alt ölçeğine aittir. Ölçeğin 18-34 arasında yer alan 17 maddesi ise olumlu tutum alt ölçeğine aittir. Ölçek "kesinlikle katılmıorum, katılmıyorum, biraz katılmıorum, biraz katılıyorum, katılıyorum ve kesinlikle katılıyorum" şeklinde 6'll likert tipinde hazırlanmıştır. Sıralanan kategoriler 1, 2, 3, 5, 6 ve 7 olarak puanlanmaktadır. Dolayısıyla her bir alt ölçekten alınabilecek puanlar 17-119 ve Yaşlılara Yönelik Tutum Ölçeği’nin tamamından alınabilecek puanlar 34-238 arasında değişmektedir. Yaşlılara yönelik olumlu tutumlar alt ölçeğinden alınan yüksek ve yaşlılara yönelik olumsuz tutumlar alt ölçeğinden alınan düşük puanlar yaşlılara yönelik olumlu tutuma sahip olunduğunu göstermektedir.

\section{Anket Formunun O̊n Uygulaması}

Kogan’ın geliştirdiği Yaşlılara Yönelik Tutum Ölçeği Duyan ve Gelbal tarafından 2013 yılında Türkçeye uyarlama çalışması yapılarak yüksek güvenirlik ve geçerlilik sağladığından ölçeğin yeniden güvenirlik ve geçerliliğinin test edilmesine gerek duyulmamıştır. Bu nedenle anketin ön uygulama aşaması geçilmiştir.

\section{Veri Toplama Araçlarının Uygullanması}

Bu araştırma Ankara Üniversitesi Sağlık Bilimleri Enstitüsü’ nün tez için belirlediği 01 Mart 2016 tarihinden itibaren 6 aylık dönemde (mülga)Aile ve 
Sosyal Politikalar Bakanlığı Müsteşarlık Makamından alınan izin dahilinde gerçekleştirilmiştir. Alınan izin ile kuruluşlara gidilerek kuruluşların idarecileriyle görüşme gerçekleştirilmiş ve araştırmanın kapsamı hakkında bilgi verilerek katılımcılara anket uygulanmıştır.

\section{Araştırmanıı Etilk Boyutu}

Araştırma Ankara Üniversitesi Etik Kurulundan 22.02.2016 tarihinde onay alınmak suretiyle etik açıdan uygun bulunmuş olup; (mülga)Aile ve Sosyal Politikalar Bakanlığı Müsteşarlık Makamı tarafından verilen kurum izniyle Bakanlık bünyesinde çalışan meslek elemanlarının katılımında gönülllülük esası temel alınarak gerçekleştirilmiştir.

\section{Verilerin Analizi}

Veri toplama süreci tamamlandıktan sonra elde edilen veriler SPSS 16 programı kullanılarak veri tabanı oluşturulmuş, değişkenlere bağlı farklılığın belirlenebilmesi amaciyla verilerin analizinde tek yönlü varyans analizi Anova ve t-test kullanılmıştır.

\section{Araş̧tırmanin Sinnirliliğı}

Araştırma, Ankara ilinde yer alan Aile, Çalışma ve Sosyal Hizmetler Bakanlığına bağlı hizmet veren kuruluşlarda gerçekleştirilmiştir. Yalnızca Ankara örneğini sunması bu araştırmanın sınırlılığıdır.

Ankete katılan personelin yıllık izin, sağlık durumu ve nöbet izinleri veya gönüllü olmama gibi gerekçelerle kuruluşlarda bulunmaması da katılımcı sayısını etkileyen bir diğer sınırlılıktır.

\section{Bullgular}

Araştırmaya dâhil olan meslek elemanlarının \%31,7'sini erkek personel, \%68,3'ünü ise kadın personel oluşturmaktadır. Personelin yaşı 24 ile 63 arasında olup yaş ortalaması 38'dir. Araştırmaya katılan çalışanların \%19,4'ünün bekâr, 
\%80,6’sının ise evli olduğu görülmektedir. Personelin \%75,4'ünün ailelerinde yaşlı birey bulunduğu, \%24,6’sında ise yaşlı birey bulunmadığ 1 belirlenmiştir.

Katılımcıların \%72,8'i lisans mezunu iken \% 20,9’u lisansüstü düzeyde eğitim görmüş olup, sağlık personeli olarak ön lisans düzeyinde çalışanların oranı ise \% 6,3 olarak belirlenmiştir. Personelinin \%23,9'u yaşlılık alanında çalıştı̆̆ını belirtmiştir. Diğer alanlarda ise \%39,9 oranında çocuk alanında, $\% 28,4$ oranında engellilik alanında, \%7,8 oranında da kadın hizmetlerinde çalışmaktadır. Araştırmaya katılan çalışanların \%30,9'u sosyal hizmet uzmanı, \%25,4'ü öğretmen, \%15,7’i sağlık servisi çalışanları olarak adlandırılan doktor, hemşire, diyetisyen, fizyoterapist, \%15,3’ü çocuk gelişimci ve \%12,7’si psikologtur.

Tablo 1'de katılımcıların sosyo-demografik özelliklerine göre yaşlılara yönelik tutum durumu yer almaktadır. 
Tablo 1. Meslek Elemanlarının Sosyo-demografik Özelliklerine Göre Yaşlılara Yönelik Tutum Puanlarının Karşılaştırılması

\begin{tabular}{|c|c|c|c|c|c|c|}
\hline & & & & & \\
\hline & & $\mathbf{N}$ & Ort. & SS & İstatistik & p \\
\hline \multirow{2}{*}{ Cinsiyet } & Erkek & 85 & 133,39 & 16,54 & \multirow{2}{*}{$t=-0,657$} & \multirow{2}{*}{, 512} \\
\hline & Kadın & 183 & 134,87 & 17,46 & & \\
\hline \multirow[t]{4}{*}{ Yaş } & $\begin{array}{l}\text { 20-30 yaş } \\
\text { arası }\end{array}$ & 75 & 134,47 & 17,17 & \multirow[t]{4}{*}{$\mathrm{F}=, 098$} & \multirow[t]{4}{*}{,961 } \\
\hline & $\begin{array}{l}\text { 31-40 yaş } \\
\text { aras1 }\end{array}$ & 84 & 133,93 & 16,68 & & \\
\hline & $\begin{array}{l}\text { 41-50 yaş } \\
\text { aras1 }\end{array}$ & 68 & 135,28 & 16,98 & & \\
\hline & $\begin{array}{c}\text { 51-65 yaş } \\
\text { aras1 }\end{array}$ & 41 & 133,78 & 18,89 & & \\
\hline \multirow[t]{2}{*}{ Medeni durum } & Evli & 216 & 134,16 & 17,05 & \multirow[t]{2}{*}{$\mathrm{t}=-, 461$} & \multirow[t]{2}{*}{,645 } \\
\hline & Bekâr & 52 & 135,38 & 17,74 & & \\
\hline \multirow{3}{*}{$\begin{array}{l}\text { Eğitim } \\
\text { durumu }\end{array}$} & Ön lisans & 17 & 120,47 & 15,90 & \multirow[t]{3}{*}{$\mathrm{F}=7,139$} & \multirow[t]{3}{*}{,001 } \\
\hline & Lisans & 195 & 134,59 & 16,58 & & \\
\hline & Lisansüstü & 56 & 137,96 & 17,67 & & \\
\hline \multirow[t]{4}{*}{$\begin{array}{l}\text { Mezuniyet } \\
\text { süresi }\end{array}$} & $\begin{array}{l}0-10 \text { yil } \\
\text { arasi }\end{array}$ & 103 & 134,24 & 17,89 & \multirow[t]{4}{*}{$\mathrm{F}=1,066$} & \multirow[t]{4}{*}{,364 } \\
\hline & $\begin{array}{l}11-20 \text { y1l } \\
\text { arası }\end{array}$ & 78 & 135,10 & 14,71 & & \\
\hline & $\begin{array}{l}21-30 \text { yil } \\
\text { arasi }\end{array}$ & 61 & 136,03 & 19,84 & & \\
\hline & $\begin{array}{l}31-40 \text { y1l } \\
\text { arasi }\end{array}$ & 26 & 129,08 & 13,77 & & \\
\hline \multirow{2}{*}{$\begin{array}{l}\text { Yaşlılıkla ilgili } \\
\text { eğitim }\end{array}$} & Var & 31 & 137,26 & 18,51 & \multirow{2}{*}{$\mathrm{t}=, 987$} & \multirow{2}{*}{,325 } \\
\hline & Yok & 237 & 134,03 & 16,98 & & \\
\hline \multirow{2}{*}{$\begin{array}{l}\text { Yaşlılık alanı } \\
\text { dışında eğitim }\end{array}$} & Var & 51 & 138,51 & 15,68 & \multirow{2}{*}{$\mathrm{t}=1,911$} & \multirow{2}{*}{,057 } \\
\hline & Yok & 217 & 133,43 & 17,38 & & \\
\hline
\end{tabular}


Tablo 1'e bakıldığında cinsiyet, yaş, medeni durum, mezuniyet süresi, yaşlılıkla ilgili veya yaşlılık alanı dışında eğitim alması durumuna göre yaşlılara yönelik tutum puanı ortalaması $(\mathrm{t}=-0,657 ; \mathrm{F}=0,98 ; \mathrm{t}=-, 461 ; \mathrm{F}=1,066 ; \mathrm{t}=, 987 ; \mathrm{t}$ $=1,911 \mathrm{p}>0.05)$ bakımından istatistiksel açıdan anlamlı bir fark yoktur. Eğitim durumuna göre yaşlılara yönelik tutum puanı $(\mathrm{F}=7,139 ; \mathrm{p}<0.05)$ bakımından istatistiksel açıdan anlamlı fark görünmektedir. Önlisans mezunları en az olumsuz tutuma sahip olan grup olarak görülmektedir. Buna karşın en olumlu tutuma sahip olan ise lisansüstü eğitim görenler olmuştur.

Yaşl1lıkla ilgili eğitim alma durumuna $(t=, 987 ; \mathrm{p}>0.05)$ ve yaşl1lı alanı dışında eğitim alma durumuna göre yaşlilara yönelik tutum $(t=1,911 ; p>0.05)$ arasında istatistiksel açıdan anlamlı bir fark yoktur.

Tablo 2'de ailede yaşı ı birey olması durumu, var ise yaşlının yakınlık derecesi, yaşlı ile yüz yüze ve telefonla görüşme sıklığına göre yaşlılara yönelik tutum durumu yer almaktadır. 
Tablo 2. Meslek elemanlarının ailesinde yaşlı birey olması durumuna göre yaşlılara yönelik tutum puanlarının karşılaştırılması

\begin{tabular}{|c|c|c|c|c|c|c|}
\hline & & & & & \\
\hline & & $\mathbf{N}$ & Ort. & SS & İstatistik & $\mathbf{p}$ \\
\hline \multirow{2}{*}{$\begin{array}{l}\text { Ailede yaşlı } \\
\text { birey }\end{array}$} & Var & 66 & 131,70 & 16,84 & \multirow{2}{*}{$\mathrm{t}=-1,477$} & \multirow{2}{*}{,141 } \\
\hline & Yok & 202 & 135,28 & 17,20 & & \\
\hline \multirow{3}{*}{$\begin{array}{l}\text { Yaşlının } \\
\text { yakınlığı }\end{array}$} & $\begin{array}{l}\text { Çekirdek aile, } \\
\text { eşin ailesi }\end{array}$ & 107 & 134,07 & 16,56 & \multirow{3}{*}{$\mathrm{F}=, 758$} & \multirow{3}{*}{470} \\
\hline & $\begin{array}{c}\text { Diğer aile } \\
\text { üyeleri, akrabalar }\end{array}$ & 84 & 136,24 & 17,48 & & \\
\hline & Her iki gruptan & 11 & 139,73 & 21,51 & & \\
\hline \multirow{6}{*}{$\begin{array}{l}\text { Yüz yüze } \\
\text { görüşsme } \\
\text { siklığ1 }\end{array}$} & Çok sık & 52 & 136,90 & 17,21 & \multirow{6}{*}{$\mathrm{F}=1,110$} & \multirow{6}{*}{,356 } \\
\hline & Sik & 35 & 136,49 & 18,36 & & \\
\hline & Ara sira & 52 & 135,67 & 17,53 & & \\
\hline & $\mathrm{Az}$ & 40 & 135,98 & 16,85 & & \\
\hline & Çok az & 7 & 130,86 & 12,13 & & \\
\hline & Diğger & 16 & 126,31 & 15,61 & & \\
\hline \multirow{6}{*}{$\begin{array}{l}\text { Telefonla } \\
\text { görüş̧me } \\
\text { s1klığı }\end{array}$} & Çok sık & 104 & 136,51 & 18,82 & \multirow{6}{*}{$\mathrm{F}=1,030$} & \multirow{6}{*}{,401 } \\
\hline & Sik & 36 & 137,69 & 14,81 & & \\
\hline & Ara sira & 15 & 136,33 & 15,68 & & \\
\hline & $\mathrm{Az}$ & 20 & 130,20 & 17,09 & & \\
\hline & Çok az & 13 & 129,85 & 14,09 & & \\
\hline & Diğer & 14 & 131,14 & 13,64 & & \\
\hline
\end{tabular}

Yaşlılara yönelik tutum ile ailede yaşlı birey olması durumu $(\mathrm{t}=-1,477$; $\mathrm{p}>0.05)$, ailede bulunan yaşlı bireyin yakınlık derecesi $(\mathrm{F}=0,758 ; \mathrm{p}>0.05)$, ailede bulunan yaşlı birey ile yüz yüze görüşme sıklığı $(F=1,110 ; p>0.05)$ ve ailede bulunan yaşlı birey ile telefonla görüşme sıklığ $(F=1,030 ; p>0.05)$ arasında istatistiksel açıdan anlamlı bir fark yoktur. Ailede bulunan yaşlılarla yüz yüze görüşme sıklığı değişkeninde gruplar arası farka bakıldığında diğer olarak isimlendirilen grup standart görüşme kalıplarına uymayacak şekilde görüşme sıklığı tarif eden kişilerden oluşmaktadır. Örneğin yılın iki ayı yaşlı 
ile birlikte yaşayıp geri kalan kısmında yüz yüze görüşmeyen kişiler bu gruba dahil edilmiştir.

Tablo 3’te meslek elemanlarının yaşlılık alanına ilgisine göre yaşlılara yönelik tutum durumları yer almaktadır.

Tablo 3. Meslek elemanlarının yaşlılık alanına ilgisine göre yaşlılara yönelik tutum durumu

\begin{tabular}{|c|c|c|c|c|c|c|}
\hline & \\
\hline & & $\mathbf{N}$ & Ort. & SS & İstatistik & p \\
\hline \multirow{2}{*}{$\begin{array}{l}\text { Yaşlılık ile ilgili } \\
\text { kitap okuma }\end{array}$} & Evet & 83 & 136,72 & 19,08 & \multirow{2}{*}{$\mathrm{t}=1,489$} & \multirow{2}{*}{,138 } \\
\hline & Hayır & 185 & 133,36 & 16,17 & & \\
\hline \multirow{2}{*}{$\begin{array}{l}\text { Medyada yaşlılıkla } \\
\text { ilgili haberleri } \\
\text { takip etme }\end{array}$} & Evet & 182 & 134,90 & 17,65 & \multirow[t]{2}{*}{$t=696$} & \multirow[t]{2}{*}{,487 } \\
\hline & Hayır & 86 & 133,34 & 16,11 & & \\
\hline \multirow{2}{*}{$\begin{array}{l}\text { Yaşlılara hizmet } \\
\text { veren bir kuruluşta } \\
\text { gönüllü çalışma }\end{array}$} & Evet & 40 & 141,70 & 21,19 & \multirow{2}{*}{$t=2,960$} & \multirow{2}{*}{,003 } \\
\hline & Hayır & 228 & 133,12 & 16,06 & & \\
\hline \multirow{2}{*}{$\begin{array}{l}\text { Gelecekte yaşlılara } \\
\text { hizmet veren bir } \\
\text { kuruluşta çalışma } \\
\text { isteği }\end{array}$} & Evet & 125 & 136,82 & 16,08 & \multirow{2}{*}{$t=2,171$} & \multirow{2}{*}{,031 } \\
\hline & Hayır & 143 & 132,29 & 17,83 & & \\
\hline
\end{tabular}

Yaşlılık ile ilgili kitap okuma durumuna ( $\mathrm{t}=1,489 ; \mathrm{p}>0.05)$, medyada yaşlılık ile ilgili haberleri takip etme durumuna $(t=696 ; p>0.05)$ ve yaşlılara hizmet veren bir kuruluşta gönüllü çalışma durumuna göre yaşlilara yönelik tutum $(\mathrm{t}=2,960 ; \mathrm{p}<0.05)$ puanı bakımından istatistiksel açıdan anlamlı fark görünmektedir. Gönüllü çalışanların çalışmayanlara göre yaşlılıkla ilgili daha fazla tutum geliştirdiği ve yaşlılara karşı daha olumlu tutuma sahip olduğu belirlenmiştir. Ayrıca gelecekte yaşlılara hizmet veren bir kuruluşta çalışma isteği durumu ile yaşlılara yönelik tutum puanı ortalaması $(\mathrm{t}=2,171 ; \mathrm{p}<0.05)$ arasında istatistiksel açıdan anlamlı bir fark görünmektedir. Gelecekte yaşlılara hizmet veren bir kuruluşta çalışmak isteyenlerin çalışmak istemeyenlere göre yaşllıkla ilgili daha fazla tutum geliştirdiği ve yaşlılara karşı daha olumlu tutuma sahip olduğu ve belirlenmiştir. 
Tablo 4’te meslek elemanlarının çalışma yaşamına ilişkin özelliklerine göre yaşlılara yönelik tutum durumu yer almaktadır.

Tablo 4. Meslek elemanlarının çalışma yaşamına ilişkin özelliklerine göre yaşıllara yönelik tutum durumu

\begin{tabular}{|c|c|c|c|c|c|c|}
\hline & & & & & \\
\hline & & $\mathbf{N}$ & Ort. & SS & Istatistik & p \\
\hline \multirow{4}{*}{ Çalışılan alan } & Engellilik & 76 & 136,88 & 18,54 & \multirow{4}{*}{$\mathrm{F}=1,686$} & \multirow{4}{*}{, 170} \\
\hline & Yaşlılık & 64 & 130,91 & 19,46 & & \\
\hline & Kadın & 21 & 137,62 & 14,72 & & \\
\hline & Çocuk & 107 & 134,09 & 14,77 & & \\
\hline \multirow{5}{*}{ Meslek } & $\begin{array}{c}\text { Diğer } \\
\text { personel }\end{array}$ & 37 & 125,84 & 16,99 & \multirow{5}{*}{$\mathrm{F}=3,595$} & \multirow{5}{*}{, 007} \\
\hline & Psikolog & 30 & 138,73 & 20,37 & & \\
\hline & $\begin{array}{c}\text { Sosyal hizmet } \\
\text { uzmanı }\end{array}$ & 73 & 137,70 & 16,40 & & \\
\hline & $\begin{array}{c}\text { Çocuk } \\
\text { gelişimcisi }\end{array}$ & 36 & 134,94 & 15,98 & & \\
\hline & Öğretmen & 60 & 135,77 & 15,94 & & \\
\hline \multirow{5}{*}{$\begin{array}{c}\text { Kurumda } \\
\text { çalışma süresi }\end{array}$} & $0-2$ yil & 48 & $1,3521 \mathrm{E} 2$ & 17,17489 & \multirow{5}{*}{$\mathrm{F}=, 140$} & \multirow{5}{*}{,967 } \\
\hline & 3-5 yll & 63 & $1,3416 \mathrm{E} 2$ & 16,81225 & & \\
\hline & $6-10$ y1l & 38 & $1,3282 \mathrm{E} 2$ & 14,53766 & & \\
\hline & $11-20$ yll & 56 & $1,3523 \mathrm{E} 2$ & 18,73741 & & \\
\hline & 21 yıl ve üzeri & 59 & $1,3458 \mathrm{E} 2$ & 18,37559 & & \\
\hline \multirow{2}{*}{ Çalışma isteği } & Alan içi & 147 & 135,68 & 16,42 & \multirow{2}{*}{$t=2,226$} & \multirow{2}{*}{, 027} \\
\hline & Alan dişı & 75 & 130,37 & 17,53 & & \\
\hline \multirow{2}{*}{$\begin{array}{l}\text { Başarılı } \\
\text { hissetme } \\
\text { durumu }\end{array}$} & Alan içi & 167 & 137,46 & 15,98 & \multirow{2}{*}{$\mathrm{t}=3,320$} & \multirow{2}{*}{, 001} \\
\hline & Alan dişı & 57 & 129,18 & 17,10 & & \\
\hline
\end{tabular}

Çalışılan alana göre yaşlılara yönelik tutum $(\mathrm{F}=1,686 ; \mathrm{p}>0.05)$ arasında istatistiksel açıdan anlamlı bir fark yoktur. Personelin mesleklerine göre 
yaşlılara yönelik tutumu incelenirken doktor, hemşire, fizyoterapist, diyetisyen gibi sağlık alanına mensup çalışanlar diğer personel adı altında bir grupta toplanmıştır. Mesleğe göre yaşlılara yönelik tutum $(\mathrm{F}=3,595 ; \mathrm{p}<0.05)$ arasında istatistiksel açıdan anlamlı fark bulunmuştur. Yapılan gruplar arası karşılaştırmada psikologlar en yüksek olumlu tutum puanına sahip grup olarak belirlenmiştir. Psikologları sırasıyla sosyal hizmet uzmanları çocuk gelişimciler, öğretmenler ve son olarak diğer personel takip etmektedir. Kurumda çalışma süresine göre yaşlılara yönelik tutum $(\mathrm{F}=, 140 ; \mathrm{p}>0.05)$ bakımından istatistiksel açıdan anlamlı bir fark yoktur.

Katılımcıların üçte ikisi sosyal hizmet alanı içinde çalışma isteklerini ifade etmiştir. Kalan üçte biri ise bu alanda çalışmak istemediklerini beyan etmiştir. Alan içinde veya alan dişında çalışma isteği ile yaşlılara yönelik tutum puanı ortalaması $(\mathrm{t}=2,226 ; \mathrm{p}<0.05)$ arasında ise istatistiksel açıdan anlamlı fark bulunmaktadır. Sosyal hizmet alanında çalışma isteğini ifade eden meslek elemanlarının yaşlılara yönelik tutumu olumlu yönde görünmektedir.

Katılımcıların dörtte üçü sosyal hizmet alanında kendisini başarılı hissettiklerini, dörtte biri ise alan dışında kendilerinin daha başarılı olacağını düşündüklerini ifade etmiştir. Alan içinde veya alan dişında başarılı hissetmeye göre yaşlılara karşı tutum puanı ortalaması $(\mathrm{t}=3,320 ; \mathrm{p}<0.05)$ arasında istatistiksel açıdan anlamlı fark görülmektedir.

\section{Tartışıma}

Aile, Çalışma ve Sosyal Hizmetler Bakanlığı bünyesinde görev yapan meslek elemanlarının yaşlılığa yönelik tutumlarını belirlemeye yönelik yapılan araştırmada elde edilen bulgular ışı̆ı̆ında; katılımcılaın cinsiyetine göre yaşlılara yönelik tutum puanları arasında istatistiksel olarak anlamlı fark bulunmamıştır $(\mathrm{t}=-0,657 ; \mathrm{p}>0.05)$. Literatüre bakıldığında cinsiyet özelliklerinin anlamlı bulunduğu çalışmalar bulunmaktadır. Örneğin Ceylan vearkadaşı (2015) sosyal hizmet bölümünde okuyan öğrencilerin yaşlı ayrımcıllğı ile ilgili tutumlarını belirlemek amacıyla yaptıkları çalışmada cinsiyet değişkenine bakılmış, erkek öğrencilerin kadın öğrencilere göre yaşlılara yönelik tutumları daha olumlu bulunmuştur. Erkek katılımcıların kadın katılımcılara göre yaşlıya yönelik tutumlarda daha olumsuz olduğunu gösteren çalışmalar bulunmaktadır 
(Elbi vd., 2015; Hawkins, 1996; Slevin, 1991;Söderhamn vd., 2001; Doherty vd., 2011). Buna karşın bazı çalışmalar yaşlilara yönelik tutumda cinsiyet değişkeni ile ilgili çelişkili sonuçlar göstermektedir. Bu durum konuyla ilgili daha fazla araştırma yapılması gerekliliğini doğurmaktadır. Mevcut çalışmalar değerlendirildiğinde genel olarak kadın katılımcıların erkek katılımcılara göre yaşlılara yönelik daha olumlu tutuma sahip oldukları görülmektedir. Bu sonuca ilişkin bir diğer örnek çalışma da Güven ve arkadaşlarının (2012) üniversite öğrencileri üzerinde yapmış olduğu araştırmadır. Bu çalışmalarda kadın katılımcıların erkek katılımcılara göre olumlu tutuma sahip olma nedeninin toplumsal cinsiyet algısı ve kültürel özelliklerin kadına yüklediği bakım verme görevinden kaynaklandığı düşünülmektedir. Farklı bir açıdan konuya yaklaşan ve katılımcının tutum puanı üzerinde yaşlı bireyin cinsiyeti ve yaş aralığının da etkili bir faktör olduğunu gösteren çalışmalar bulunmaktadır (Ceylan vd., 2015; Hawkins, 1996).

Personelin yaşına göre yaşlılara yönelik tutumlarına bakıldığında istatistiksel açıdan anlamlı bir fark yoktur $(F=, 098 ; p>0.05)$. Literatürde bu bulguyu destekleyen başka çalışmalar da mevcuttur (Aydın vd., 2016; Hawkins, 1996). Ancak bazı çalışmalarda tecrübe, yaş ve cinsiyetin yaşllara yönelik tutumlar konusunda etkili faktörler olduğu söylenmiştir. Yaş itibarıyla 25 yaşından büyük olan öğrencilerin 25 yaşından küçük olanlara göre daha olumlu bir tutuma sahip oldukları görülmüștür (Söderhamn vd., 2001). Gomez ve arkadaşları (1985) 31-40 yaş arasındaki öğrencilerin daha genç olanlardan daha olumlu tutum sergilediğini ortaya koymuştur. Aynı şekilde bir diğer çalışma öğrencilerin yaşının ilerledikçe tutumun pozitif yönde geliştiğini göstermiştir (Güven vd.,2012). Sonuçlar değerlendirildiğinde bazı çalışmalarda öğrencilerin yaş ile olgunluk düzeyindeki artışın tutumu pozitif yönde etkilediği görülürken bazı çalışmalarda da anlamlı bir fark bulunamamıştır. Bu nedenle araştırmalarda bu konuya yer verilmesi önem arz etmektedir.

Personelin medeni durumuna göre yaşlılara karşı tutumları arasında istatistiksel açıdan anlamlı bir fark bulunmamıştır ( $\mathrm{t}=-, 461 ; \mathrm{p}>0.05)$. Bir diğer çalışmada da benzer sonuç bulunmuş olup gruplar arasında istatistiksel açıdan anlamlı fark bulunmamıştır (Ünalan vd., 2012). Araştırmanın yapıldığı 
ülke, coğrafi ve kültürel farklılık bu sonucu değiştirebilir. Başka bölgelerde de bu hususun araştırılabileceği düşünülmektedir.

Eğitim durumu ile yaşlılara karşı tutum arasında istatistiksel açıdan anlamlılık görülmektedir $(\mathrm{F}=7,139 ; \mathrm{p}<0.05)$ ve en olumlu puana sahip grup önlisans mezunlarıdır.Bunun nedeni düşükeğitim düzeyine sahipkatılımcıların geleneksel Türk aile yapısını muhafaza etmeleri olarak düşünülmektedir. Ünalan ve arkadaşları tarafından yapılan çalışmanın eğitimle ilgili bulguları çalışmamızın eğitimle ilgili bulgusunu desteklemektedir. Üniversite mezunu olan çalışanların Yaşlı Ayrımcılığı Tutum Ölçeğinden aldıkları tutum puan ortalamalarının lise ve ilköğretim mezunu çalışanlara göre anlamlı derecede düşük olduğu bulunmuştur. Ünalan ve arkadaşları bu bulguyu yükseköğrenim görmüş olan personelin kariyer beklentisine yormuşlardır. Çalışma sonucumuzun aksine eğitim düzeyi arttıkça yaşlıya yönelik olumlu tutumun önemli ölçüde arttığını saptayan çalışmalar da bulunmaktadır (Doherty vd., 2011; Courtney vd., 2000; Armstrong-Esther vd., 1989; Gomez vd., 1985).

Yaşlllıkla ilgili eğitim alma durumu ile yaşlılara yönelik tutum arasında istatistiksel açıdan anlamlı bir fark yoktur. Literatürde bu bulgunun aksine sonuçları gösteren birçok çalışma mevcuttur (Cozort, 2008; Ferrario vd., 2007; Intrieri vd., Castilla, 1993; Warren, 1983). Özcan ve arkadaşları (2013) ise tartışmalı bir sonuç elde etmiştir. Çalışmalarında yaşlılıkla ilgili eğitimin tıp öğrencilerinin büyük çoğunluğunda pozitif tutumun artışını sağlarken bir kısmında ise tutumun negatif yönde etkilendiğini göstermiştir. McLafferty ve Morrison, (2004) farklı bir bakış açısı ortaya koyarak eğitim verilen fakültelerin yaşlı bakımında uzman olmadığında olumsuz tutumları teşvik ettiğini belirtmiştir. Çalışmada elde edilen sonucun nedeninin örneklem çeşitliliğinden ileri gelebileceği düşünülmektedir. Yalnızca yaşlılık alanında çalışan veya çalışacak olan personel ile yapılmaması sonucu etkilemiş olabilir. $\mathrm{Bu}$ konuda net bilgi elde edilebilmesi için daha spesifik bir çalışmaya ihtiyaç olduğu değerlendirilmektedir.

Ailede bulunan yaşlı birey ile yüz yüze görüşme sıklığına göre yaşlılara yönelik tutum puanı ortalaması arasında anlamlı fark bulunmamıştır. Çok sık ve sık görüşen katılımcıların diğer bütün gruplardan daha olumsuz tutuma sahip oldukları belirlenmiştir. Ancak "diğer" olarak adlandırılan grup en 
az olumsuz tutuma sahiptir. Bu grup, standart görüşme sıklı̆̆ kalıplarına uymayacak şekilde görüşme sıklığı tarif eden kişilerden oluşmaktadır. Örneğin yılın iki ayı birlikte yaşayıp geri kalan kısmında ailedeki yaşlı bireyle yüz yüze görüşmeyen kişiler bu gruba dahil edilmiştir. Olumsuz tutum geliştirmeme nedeninin katılımcının yılın belli bir zamanını aralıksız olarak ailedeki yaşlı bireye ayırdığı düşüncesiyle sorumluluğunu yerine getirme hissi ile bağlantılı olabileceği düşünülmektedir. Bu nedenle iletişimin sıklığından ziyade iletişimin kalitesinin önem kazandığ düşünülmektedir. Yaşlı bireylerle iletişimin sıklığından ziyade kalitesinin tutum üzerinde etkili olduğunu gösteren çalışmalar bulunmaktadır (Drury vd., 2016; Schwarz ve Simmons, 2001). Literatürde yaşlı birey ile ilişkiler azaldıkça bireyler arası etiketlemeler ve kalıp yargıların geliştiği, olumsuz tutum ve davranışlara zemin oluşturduğu bildirilmektedir (Canatan, 2008). Görüşme sıklığını çok sık veya çok az olarak tarif eden gruplar arasında ise tutum puanı açısından anlamlı fark bulunmamıştır. Literatürde yaşlı bireyle yaşıyor olma veya ziyaret etme sıklığının yaşlı bireylere yönelik tutum arasında kayda değer anlamlı bir ilişki bulunmadığı çalışmalar bulunmaktadır (Aydın vd.,2016; Hawkins, 1996). Ayrıca katılımcıların yaşlılarla kurdukları duygusal ilişkilerin öğrencilerin yaşlılara ve yaşlılarla sosyal hizmete karşı tutumunu etkilediğini, yaşlı bireyle deneyim ve yaşanmışlı̆̆ın tutumu olumlu yönde etkilediğini doğrulayan araştırmalar mevcuttur (Ünalan vd., 2012; Tufan, 2002; Quinn,1999).

Yaşlilara hizmet veren bir kuruluşta gönüllü çalışma durumu ile yaşlllara yönelik pozitif tutum arasındaki ilişkiye bakıldığında gönüllü olarak yaşlllara hizmet veren bir kuruluşta çalışan katılımcıların gönüllü çalışmayanlara göre yaşlilara karşı daha fazla tutum geliştirdikleri ve daha olumlu bir tutuma sahip oldukları ortaya çıkmıştır. Bu bulgu yaşlılarla ilgili olumlu tutum beklentisini karşılamaktadır. Literatür yaşlılık alanında çalışma konusunda öğrencilerin isteksiz olduğu ve yaşlılık alanının tercih edilen bir alan olmadığını (Humphries vd, 2008; Buchan ve Seccombe, 2006) ve bu durumun negatif tutumlardan kaynaklandığını göstermektedir (McKinlay ve Cowan, 2003; Dellasega ve Curriero, 1991). Wade (1999) sürekli bakım ortamlarındaki iş yükünün rutinleştirilmiş ve fiziksel olarak tarif edilen bakımın ağır görüldüğünü açılamıştır. 
Gelecekte yaşlılara hizmet veren bir kuruluşta çalışma isteği durumu ile yaşlılara karşı yaşlılara karşı tutum puanı ortalaması bakımından istatistiksel açıdan anlamlı görünmektedir. Gelecekte yaşlılara hizmet veren bir kuruluşta çalışmak isteyenlerin çalışmak istemeyenlere göre yaşlılıkla ilgili daha fazla tutum geliştirdiği ve yaşlılara karşı daha olumlu tutuma sahip olduğu belirlenmiştir. Yaşlılara yönelik olumlu tutum geliştirdiği anlaşılan bu grubun gelecekte de yaşlılarla birlikte çalışma isteği bildirmesi beklenen bir sonuçtur.

Sosyal hizmetin dört ana alanından (engellilik, yaşlılık, çocuk ve kadın alanı) çalışılan alana göre yaşlılara yönelik tutum arasında istatistiksel açıdan anlamlı bir fark yoktur.

Mesleğe göre yaşlılara yönelik tutum puanı bakımından istatistiksel açıdan anlamlı bir fark bulunmuştur $(\mathrm{F}=3,595 ; \mathrm{p}<0.05)$. Diğer personel adı altında toplanan katılımcılar doktor, hemşire, fizyoterapist, diyetisyen, acil tıp teknisyeni gibi meslek gruplarından oluşturulmuştur. Yapılan gruplar arası karşılaştırmada psikologlar en yüksek olumlu tutum puanına sahip grup olarak belirlenmiştir. Psikologları sırasıyla sosyal hizmet uzmanları çocuk gelişimciler, öğretmenler ve son olarak diğer personel takip etmektedir. Literatürde sağlık birimlerinin toplumda en çok olumsuz tutumların görüldüğü alanlardan biri olduğu bildirilmektedir (Vefikuluçay, 2008).Bu yönüyle araştırma literatürle bağdaşmaktadır. Aksini ortaya koyan bir başka çalışma (Cankurtaran vd.,2006) tıp fakültesi öğrencilerinin yaşlılara karşı tutumun olumlu olduğunu ortaya koymuştur.

Çalışılan kuruluşta çalışma süresine göre yaşlılara yönelik tutum arasında istatistiksel açıdan anlamlı fark bulunmamıştır $(\mathrm{F}=, 140 ; \mathrm{p}>0.05)$. Bazı araştırmalar bu araştırmada olduğu gibi çalışma süresiyle tutum arasında anlamlı fark olmadığını ortaya koymaktadır. (Aydın vd., 2016; Doherty vd., 2011).

Sosyal hizmet alanı içinde veya alan dışında çalışma isteğine göre yaşlılara yönelik tutum puanı ortalaması istatistiksel açıdan anlamlı bulunmuştur $(t=2,226 ; \mathrm{p}<0.05)$. Alan içinde çalışmaya devam etmek istediğini bildiren katılımcıların tutum puanı alan dışında çalışmak isteyenlerden yüksek bulunmuştur. Gunter (1971) çalışmasında yaşlılara yönelik olumlu 
tutumun kariyer seçeneğiyle birebir ilişkili olmadığını göstermiştir. Literatür yaşlılık alanında çalışma konusunda öğrencilerin isteksiz olduğu ve yaşlılık alanının tercih edilen bir alan olmadığını (Humphries vd., 2008; Buchan ve Seccombe, 2006) ve bu durumun olumsuz tutumlardan kaynaklandığını göstermektedir (McKinlay ve Cowan, 2003; Dellasega ve Curriero, 1991). Wade (1999) sürekli bakım ortamlarındaki iş yükünün rutinleştirilmiş ve fiziksel olarak tarif edilen bakımın ağır görüldüğünü açıklamıştır. Buna ilişkin bakım personeliyle yapılan bir çalışmada çalışma süresiyle kaçınma düzeyinin artış gösterdiği ve haftalık yasal çalışma süresinin üzerinde çalışan bakım personelinin de yaşl1lığa yönelik olumsuz tutuma sahip olduğu bildirilmiştir (Arun ve Pamuk, 2014).

Meslek elemanlarının sosyal hizmet alanında kendini başarılı hissetme durumuna göre yaşlılara karşı tutum arasında istatistiksel açıdan anlamlı fark bulunmuştur $(t=3,320 ; p<0.05)$. Sosyal hizmet alanı içinde kendini başarılı hissettiğini ifade eden katılımcıların tutum puanı ortalamaları kendini bu alanda başarılı hissetmeyen katılımcılardan anlamlı düzeyde yüksek çıkmıştır. Sosyal hizmet alanında kendini başarılı hissetmenin mesleki olarak yetkinliğe sahip olma, kendini tanıma ve sorun çözme becerisi gibi unsurlarla ilişkili olduğu düşünülmektedir. Buna karşın Bir çalışmada sosyal hizmet uzmanlarının sorun çözme becerisine göre mesleği devam ettirme motivasyon durumları arasında anlamlı bir fark bulunmadığı bildirilmiştir (Koç S., 2015;ss.168).

Ailede yaşlı birey olması durumu, ailede bulunan yaşlı bireyin yakınlık derecesi, ailede bulunan yaşlı birey ile telefonla görüşme sıklığı, yaşlılık ile ilgili kitap okuma durumu, medyada yaşlılık ile ilgili haberleri takip etme durumu, mezuniyet yılı, yaşlılık dışında eğitim alma durumu ve kurumda çalışma süresi ile yaşlılara karşı tutum arasında istatistiksel açıdan anlamlı bir fark yoktur. 


\section{Sonuç ve Öneriler}

Sonuç olarak;

1- Gönüllü olarak yaşlılara hizmet veren bir kuruluşta çalıştığını belirten katılımcıların tutum puan ortalamalarının çalışmadığını belirten katılımcilardan yüksek olduğu;

2- Gelecekte yaşlılara hizmet veren bir kuruluşta çalışmak istediklerini belirten katılımcıların tutum puanının çalışmak istemeyen katılımcılardan yüksek olduğu;

3- Eğitim durumu ile yaşlılara karşı tutuma bakıldığında önlisans mezunu kişilerin tutum puanının lisans ve yüksek lisans mezunlarına göre yüksek olduğu;

4- Mesleğe göre yaşlılara karşı tutuma bakıldığında en yüksek tutum puanından en düşüğe doğru mesleklerin sıralamasında psikolog, sosyal hizmet uzmanı, öğretmen, çocuk gelişimci ve diğer personelin yer aldığı;

5- Sosyal hizmet alanı içinde kendini başarılı hissettiğini ifade eden katılımcıların tutum puanı ortalamalarının kendini bu alanda başarılı hissetmeyen katılımcılardan anlamlı düzeyde yüksek olduğu bulunmuştur. Çalışmaya ilişkin öneriler aşağıda sıralanmıştır;

1- Çalışma daha geniş kapsamlı bilgi elde edebilmek amacıyla tüm meslek elemanları ile yapılmış olsa da gelecek araştırmalarda sadece yaşlılık alanında çalışan örneklem ile çalışılmasının araştırmanın değişkenleri arasındaki ilişkinin daha sağlıklı test edilmesine olanak sağlayacağı düşünülmektedir.

2- Çalışmanın diğer illerde de uygulanması profesyonellerin profilinin tam olarak ortaya konmasına katkı sağlayacaktır. Bakanlığa bağlı olarak hizmet veren yaşlı hizmet kuruluşlarında görev alan personele yönelik hizmet içi eğitimlerde ön test ve son test olarak uygulanması önerilmektedir. Böylece personelin yaşlılığa yönelik tutum profili somutlaştırılmış olacaktır.

3- Yaşlılık alanına personel seçiminde tutum ve yetkinlik ölçümünün yapılması 
insan kaynağından en yüksek verimin elde edilmesine katkıda bulunacaktır. Nüfusun yaşlanması diğer ülkeler gibi Türkiye için de kaçınılmaz bir durum iken hizmet kalitesinin desteklenmesi ve hizmet sağlayıcı profesyonellerin bu alanda yetiştirilmesi adına eğitim modüllerinin ve ölçüm araçlarının sistemli olarak kullanılmaya başlanması bir gerekliliktir.

4- Akademik ortam ve hizmet ortamının aynı lisanı konuşması, standardın oluşabilmesi adına bu ölçüm araçlarının kullanılması önerilmektedir. Bu çalışma ile yetkinliğin oluşumunda yaşl1lık ile ilgili eğitimin önemine vurgu yapılmaktadır. Bu nedenle gerontolojik içeriğin fakültelerde de müfredata eklenmesi önem arz etmektedir. 


\section{Kaynalklar}

Allan L. J. \& Johnson, J. A. (2009). Undergraduate attitudes toward the elderly: The role of knowledge, contact and aging anxiety. Educational Gerontology; 35: 1-14.

Armstrong-Esther C.A., Sandilands, M.L., Miller, D. (1989). Attitudes and behaviours of nurses towards the elderly in an acute care setting. Journal of Advanced Nursing; 14: 34-41.

Arun O.\& Pamuk D. (2014). Kurumsal Bakım Sektöründe Ageism: Yaşlı Bakım Personelinin Yaşlanma ve Yaşlılığa İlişkin Ayrımcı Tutumlarının Nedenleri ve Müdahale Önerileri. Mediterranean Journal of Humanities mjh.akdeniz.edu.tr IV/2, 2014, 19-33 DOI: 10.13114/MJH.201428426

Aydın L., Yönt, G. H., Bayat, E., \& Günay, B. (2016). Hemşirelerin Yaşlılara Yönelik Tutumları ve Etkileyen Faktörlerin Belirlenmesi. Yıldırım Beyazıt Üniversitesi Hemşirelik E-Dergisi;3(1).

Buchan J.\& Seccombe I. (2006). Worlds Apart? The UK and International Nurses, RCN, London, UK.

Canatan A. (2008). “Toplumsal Değerler ve Yaşlılar”.Yaşlı Sorunları Araştırma Dergisi; (1):62-71

Cankurtaran M. (2005). Yaşlılık, Yaşlanma Mekanizmaları, Antiaging ve Yaşam Tarzı Değişiklikleri. 7. Ulusal İç Hastalıkları Kongresi. Antalya.

Ceylan H.\& Öksüz M. (2015). Sosyal Hizmet Lisans Öğrencilerinin Yaşlı Ayrımcılığına İlişkin Tutumlarının İncelenmesi. Journal of International Social Research; 8(39).

Cheong, S. K., Wong, T. Y., \& Koh, G. C. (2009). Attitudes towards the elderly among Singapore medical students. Annals Academy of Medicine Singapore; 38(10), 857.

Cozort R. W. (2008). Student nurses' attitudes regarding older adults: Strategies for fostering improvement through academia. Teaching and Learning in Nursing; 3(1), 21-25.

Dalley, G. (1996). Hughes Beverley, Older People and Community Care: Critical Theory and Practice, Open University Press, Buckingham and Philadelphia, 1995, 146 pp., hbk£ 37.50, ISBN 033519157 6, pbk£ 13.99, ISBN 033519156 8. Ageing \& Society, 16(4), 515-517.

Dellasega C. \& Curriero F.C. (1991) The effects of institutional and community experiences on nursing students' intentions toward work with the elderly. Journal of Nursing Education;30(9), 405-410. 
Depaola, S. J., Neimeyer, R., \& Ross, S. K. (1994). Death concern and attitudes toward the elderly in nursing home personnel as a function of training. OMEGA-Journal of Death and Dying; 29(3), 231-248.

Doherty M, Mitchell Ea, O'neill S. (2011). Attitudes of health care workers towards older people in a rural popula-tion: A survey using the Kogan Scale. Nursing Research and Practice; Article ID 352627: 1-7.

Drury L., Hutchison P., \& Abrams D. (2016). Direct and extended intergenerational contact and young people's attitudes towards older adults. British Journal of Social Psychology; 55(3), 522-543.

Duyan, V., \& Gelbal, S. (2013). Yaşlılara Yönelik Tutum Ölçeğinin Bir Grup Üniversite Öğrencisi Üzerinde Türkçeye Uyarlama Çalışması. Turkish Journal of Geriatrics; 16(2), 202-209.

Elbi H., Altan S., Rahman S., Cengiz Özyurt B., Şahin S., \& Çam F. S. (2015). The Attitudes Of Medical Students Toward The Elderly. Turkish Journal of Geriatrics/Türk Geriatri Dergisi; 18(4).

Fagerberg I. \& Ekman S. L. (1997). First-year Swedish nursing students' experiences with elderly patients. Western Journal of Nursing Research; 19(2), 177-189.

Ferrario C. G., Freeman F. J., Nellett G., \& Scheel J. (2007). Changing nursing students' attitudes about aging: An argument for the successful aging paradigm. Educational Gerontology; 34(1), 51-66.

Gallagher S., Bennett K. M. \& Halford J. C. (2006). A comparison of acute and longterm health-care personnel's attitudes towards older adults. International Journal of Nursing Practice; 12(5), 273-279.

Gomez G., Otto D., Blattstein A., \& Gomez E. (1985). Beginning nursing students can change attitudes about the aged. Journal of Gerontological Nursing; 11 (1), 6-11.

Gorelik Y., Damron-Rodriguez J., Funderbunk B., \& Solomon D. H. (2000). Undergraduate interest in aging: Is it affected by contact with older adults? Educational Gerontology; 26(7), 623-638.

Gunter L. (1971). Students' attitudes toward geriatric nursing. Nursing Outlook; 19, 466469.

Güven, Ş., Muz, G. U., \& Ertürk, N. E.(2012). Üniversite öğrencilerinin yaşlı ayrımcılığına ilişkin tutumları ve bu tutumların bazı değişkenlerle ilişkisi. Anadolu Hemşirelik ve Sağlık Bilimleri Dergisi; 15(2), 99-105.

Hablemitoğlu, Ş., Özmete, E., Bayoğlu, A. S., \& Yıldırım, F. (2011).Evde Yaşlı Bakımı 
Hizmetlerinde Gönüllü Olmanın Gençlerin Yaşamlarına Katkısı. C.Ü. İktisadi ve İdari Bilimler Dergisi, Cilt 12, Say1 1(ss.147-162)

Hawkins M. J. (1996). College Students'attıtudes Toward Elderly Persons. Educational Gerontology: An International Quarterly; 22(3), 271-279.

Hellzén, O., Kristiansen, L., \& Norbergh, K. G. (2003). Nurses' attitudes towards older residents with long-term schizophrenia. Journal of Advanced Nursing; 43(6): 616-622.

Humphries N., Brugha R. \& Mcgee H. (2008). "Overseas nurse recruitment: Ireland as an illustration of the dynamic nature of nurse migration," Health Policy; vol. 87 (2): 264-272.

Intrieri R.C., Kelly J.A., Brown M.M. \& Castilla C. (1993). Improving medical students' attitudes toward and skills with the elderly. The Gerontologist; 13(3): 373-378.

Jack R.\& Mosley S. (1997). The client group preferences of diploma in social work students: What are they, do they change during programmes and what variables affect them? British Journal of Social Work; 27: 893-911.

Schwartz K., Joseph P., Simmons L. (2001). Contact quality and attitudes toward the elderly. Educational Gerontology; 27(2): 127-137.

Kaempfer, D., Wellman, N. S., \& Himburg, S. P. (2002). Dietetics students' low knowledge, attitudes, and work preferences toward older adults indicate need for improved education about aging. Journal of the American Dietetic Association; 102(2): 197-202.

Koç, S. Ç. (2015). Sosyal Hizmet Uzmanlarının Sorun Çözme Becerileri Üzerine Bir Araştırma. Yüksek Lisans Tezi, Ankara.

Liu, Y. E., While, A. E., Norman, I. J., \& Ye, W. (2012). Health professionals' attitudes toward older people and older patients: A systematic review. Journal of interprofessional care; 26(5): 397-409.

Mason, S. E., \& Sanders, G. R. (2004). Social work student attitudes on working with older clients. Journal of Gerontological Social Work; 42(3-4): 61-75.

Mckınlay A.\& Cowan, S. (2003). Student nurses' attitudes towards working with older patients. Journal of advanced nursing; 43(3): 298-309.

Mclafferty, I., \& Morrison, F. (2004). Attitudes towards hospitalized older adults. Journal of Advanced Nursing; 47(4): 446-453.

Öz F. (2002). Yaşamın Son Evresi: Yaşlılık Psikososyal Açıdan Gözden Geçirme, Kriz Dergisi; 10(2):17-28

Özcan S., Duyan V., Koç F., \& Bozdemir N. (2013). Üçüncü Sınıf Tip Öğrencilerinin 
Yaşlılara Yönelik Tutumları: Bir Eğitim Programının Etkisinin Değerlendirilmesi. Turkish Journal of Geriatrics/Türk Geriatri Dergisi, 16(2).

Özpınar S.\& Korkmaz M. (2017). Kurumda Ve Evde Yaşayan Yaşlı Bireylerin Yaşlılık Algısı İle İlgili Tutumları Ve Etkileyen Faktörler. In 19. Ulusal Halk Sağlığı Kongresi.

Özyurt B. C., Tunç B., \& Hatipoğlu S. (2013). Yaşlıların yaşlılıkla ilgili tutumları: Manisa'da bir kentsel ve kırsal bölge örneği. Akademik Geriatri; 5: 29-37.

Peace J. (1996). The values of social work. In A. A. Vass (Ed.), Social work competences: Core knowledge, values, and skills pp. 36-61. London: Sage Publications.

Quinn A. (1999). The use of experiential learning to help social work students assess their attitudes towards practice with older people. Social Work Education; 18(2): 171-182.

Scharlach A., Damron-Rodriguez J., Robinson B., \& Feldman R. (2000). Educating social workers for an aging society: A vision for the 21st. Century. Journal of Social Work Education; 36(3): 521-538.

Slevin O. Ď. (1991). Ageist attitudes among young adults: implications for a caring profession. Journal of advanced nursing;16(10): 1197-1205.

Söderhamn O, Lindercrona C, Gustavsson S.M. (2001). Attitudes toward older people among nursing students and registered nurses in Sweden. Nursing Education Today; 21(3): 225-229.

Tufan, İ. (2007). Birinci Türkiye Yaşlilık Raporu, Antalya, GeroYay.

Tufan, İ.(2006) Antik Çağ’dan Günümüze Yaşlılık ve Yaşlanma. Ankara. Nobel Akademik Yayıncilı,

Ünalan D., Soyuer F. \& Elmalı F. (2012). Geriatri merkezi çalışanlarında yaşlı tutumunun değerlendirilmesi. Kafkas Tip Bilimleri Dergisi; 2(3): 115-120.

Vefikuluçay D. (2008). Üniversitede öğrenim gören öğrencilerin yaşlı ayrımcılı̆̆ına ilişkin tutumları. Yayınlanmış Doktora Tezi, Hacettepe Üniversitesi Sağlık Bilimleri Enstitüsü, Ankara.

Wade S. (1999). Promoting quality of care for older people: developing positive attitudes to working with older people. Journal of Nursing Management; 7(6): 339-347.

Warren D. L., Painter A. \& Rudisill J. (1983). Effects of geriatric education on the attitudes of medical students. Journal of the American Geriatrics Society; 31(7): 435-438. 